\title{
A CRITICAL ANALYSIS OF THE BARRIERS TO ENTRY FOR SMALL BUSINESS OWNERS IMPOSED BY SECTIONS $12 \varepsilon(4)(A)(I I I)$ AND (D) AND PARAGRAPH 3(B) OF THE SIXTH SCHEDULE OF THE INCOME TAX ACT, No. 58 of 1962
}

\author{
Leonard Willemse* \\ University of Stellenbosch \\ Iwillemse@sun.ac.za
}

December 2011

\begin{abstract}
According to National Treasury's Explanatory Memorandum on the Revenue Laws Amendment Bill, 2008, small businesses in South Africa are instrumental in the growth of the South African economy as they are a source of job creation and a counter to poverty. Research, however, indicates that small businesses face many obstacles, such as relatively high tax compliance costs. It was, therefore, proposed in the 2008 Budget Review that a turnover tax system be implemented for micro businesses with a turnover of up to Rl million per annum to simplify the tax compliance process. Similarly, section $12 \varepsilon$ was introduced earlier in the Income Tax Act No. 58 of 1962 to offer additional income tax relief to small business owners. Sections $12 \varepsilon(4)(a)(i i i)$ and (d) and paragraph $3(b)$ of the Sixth Schedule, however, prevent certain small business owners from making use of these concessions. This article investigates these barriers to entry and explores possible solutions to the problems presented by them.
\end{abstract}

Keywords

Income Tax Act No. 58 of 1962 (as amended), micro business, personal services, professional, profession, professional services, small business, small business corporation.

*Mr Leonard C Willemse is a senior lecturer at the University of Stellenbosch, South Africa. 


\section{INTRODUCTION AND BACKGROUND}

According to the Explanatory Memorandum on the Revenue Laws Amendment Bill, 2008 (National Treasury, 2008:55) small businesses in South Africa are instrumental in the growth of the South African economy as they are a source of job creation and a counter to poverty. Research, however, indicates that small businesses face many obstacles, such as relatively high tax compliance costs as a percentage of their turnover. This is due to the generally high fixed costs associated with systems necessary to comply with the requirements of the tax system. The reality is that many small businesses are outside the income tax net either because they generate small profits or because they are overwhelmed by the tax system. It was, therefore, proposed in the 2008 Budget Review that a turnover tax system be implemented for micro businesses with a turnover of up to Rl million per annum. This instrument will effectively replace income tax, capital gains tax (CGT), dividend withholding tax and value added tax (VAT) for qualifying micro businesses. Payroll taxes such as PAYE and UIF contributions are excluded because they are taxes generally borne by employees and collected by employers on behalf of the State (Legal and Policy Division of the South African Revenue Services, 2011: 5).

Turnover tax payable by micro businesses is regulated by section 48 and the Sixth Schedule of the Income Tax Act No. 58 of 1962 (hereafter referred to as 'the Act'). Section 48 and the Sixth Schedule were inserted by section 54(1) of the Revenue Laws Amendment Act, 2008 which took effect from 1 March 2009 and is applicable in respect of a year of assessment commencing on or after that date.

An earlier special dispensation introduced by the South African government for small businesses (which is currently still in force) is the Small Business Corporation (SBC) legislation. The SBC legislation was introduced with effect from years of assessment commencing on or afterl April 2000 (Mkhize, 2011:11). The SBC legislation provides for two key concessions to qualifying small businesses. The first concession is the progressive tax rates, which are lower than normal tax rates at a taxable income level below R350 000. The second concession is that the qualifying small business is entitled to special capital allowances (Mkhize, 2011:5). According to Mkhize (2011:15) SBC legislation was introduced for the purpose of encouraging the establishment of new start-up businesses and job creation.

\section{PROBLEM STATEMENT}

A taxpayer can only make use of the aforementioned concessions and tax incentives if he or she meets the criteria set by the relevant sections of the Act. Paragraph 2(1) of the Sixth Schedule of the Act sets out the requirements a person must meet to qualify as a micro business for turnover tax purposes:

2(1)A person qualifies as a micro business if that person is a-

(a) natural person (or the deceased or insolvent estate of a natural person that was a registered micro business at the time of death or insolvency); or

(b) company,

where the qualifying turnover of that person for the year of assessment does not exceed an amount of Rl million. 
Section $12 \varepsilon(4)(a)$ of the Act defines a $S B C$ as any close corporation, co-operative or any private company whose shareholders are all natural persons, and whose gross income does not exceedR14 million during the year of assessment (Mkhize, 2011:11).

Although a person might meet the abovementioned requirements, both turnover tax- and SBC legislation impose barriers to entry for certain taxpayers. Paragraph 3 of the Sixth Schedule lists the persons who explicitly do not qualify as a micro business and who are therefore not allowed to make use of the Turnover Tax system. Similarly, section $12 \varepsilon(4)$ excludes certain types of taxpayers from qualifying as a SBC. This research article specifically investigates the barriers to entry imposed on taxpayers by paragraph $3(\mathrm{~b})$ of the Sixth Schedule and sections $12 \varepsilon(4)$ (a)(iii) and (d) of the Act.

The exclusion under paragraph 3(b) of the Sixth Schedule reads as follows:

3. A person does not qualify as a micro business for a year of assessment where -

(b) more than $20 \%$ of that person's total receipts during that year of assessment consist of -

I. insolvent estate of a natural person that was a registered micro business at the time of death or insolvency), income from the rendering of a professional service; and where that person is a natural person (or the deceased or

II. where that person is a company, investment income and income from the rendering of a professional service;

It follows that "professional service" is defined in paragraph 1 of the Sixth Schedule and means a service in the field of accounting, actuarial science, architecture, auctioneering, auditing, broadcasting, consulting, draftmanship, education, engineering, financial service broking, health, information technology, journalism, law, management, real estate broking, research, sport, surveying, translation, valuation or veterinary science (own emphasis).

According to Stiglingh, Koekemoer, van Schalkwyk, Wilcocks, de Swardt and Jordaan (2011:438) a person does not qualify as a SBC (in terms of section $12 \varepsilon(4)$ (a) (iii)) if more than $20 \%$ of the total receipts and accruals of the corporation consists collectively of investment income (as defined in section $12 \varepsilon(4)(c)$ ) and income from the rendering of personal services. 'Personal service' is defined in section $12 \varepsilon(4)(d)$ and means, in relation to a company or close corporation, any service in the field of accounting, actuarial science, architecture, auctioneering, auditing, broadcasting, consulting, draftmanship, education, engineering, financial service broking, health, information technology, journalism, law, management, real estate broking, research, sport, surveying, translation, valuation or veterinary science, if the service is performed by any person who holds an interest in the SBC and that company or close corporation does not throughout the year of assessment employ three or more full-time employees (other than any employee who is a shareholder of the company or the close corporation, as the case may be, or who is a connected person in relation to a shareholder or member), who are on a full-time basis engaged in the business of that company or close corporation of rendering that service.

It should be noted that services constitute personal services only if the person performing the services is someone who holds an interest in the SBC. In other words, services performed by persons who do not hold such an interest will not qualify as personal services (De Koker, 2011a).

The services listed under paragraph 1 and section $12 \varepsilon(4)(d)$ are identical. The list is quite extensive but can also be seen as vague. According to the Explanatory Memorandum on the Revenue Laws Amendment Bill, 2008 (National Treasury, 2008:59) the Sixth Schedule will not apply where the micro business renders a 'professional service' as described in the 
abovementioned definition. The Memorandum goes on to state that the exclusion of 'professional service' from the definition of a micro business is an anti-avoidance measure to protect the employment income tax base and that such professional services are generally rendered by more sophisticated, high-income-earning taxpayers, with profit margins that are significantly higher than those assumed in the design of the turnover tax. It is, however, respectfully submitted that this explanation does not effectively assist with the establishment of parameters within which a service is deemed to be professional for purposes of the Sixth Schedule.

Furthermore, paragraph 1 refers to 'a service' whereas section $12 \varepsilon(4)(d)$ refers to 'any service'. The use of the words ' $a$ ' and 'any' causes further confusion as the word ' $a$ ' seems to indicate a specific element, whereas the word 'any' seems to refer to something more in general. Can it therefore be inferred, due to the fact that paragraph 1 and section $12 \varepsilon(4)(d)$ list exactly the same services, that a professional service is a personal service, or vice versa?

According to Mkhize (2011:36) the definitions of personal service and professional service are partly similar. The difference is that the definition of personal service restricts the number of employees to two whereas professional service does not restrict the number of employees. Mkhize (2011:36) also states that the effect of this provision is that if a company employs three or more employees, its income from personal service can exceed $20 \%$ of its total receipts and still qualify for SBC legislation. However, under turnover tax, income from rendering professional service will always be restricted to $20 \%$ irrespective of the number of employees. SBC legislation is, therefore, more accessible than turnover tax in this respect. If it is assumed (for purposes of this article) that the words 'personal' and 'professional' carry the same meaning (save for the exclusion with regard to the number of employees), one can investigate the significance of the word 'professional' and fundamental principles associated therewith.

Taking the above discussion into consideration, the definition of professional service poses a potential interpretation problem. It begs the question how professional must a taxpayer's service be in order for it to be classified as 'professional' for purposes of the Sixth Schedule and section $12 \varepsilon$ ? Furthermore, how sophisticated must a taxpayer be, before his services will be considered professional? Currently, only a list of certain activities is given in the Sixth Schedule and section $12 \varepsilon$ that are seen as professional, for example, sport, health and entertainment. However, none of these activities is clearly defined in the Income Tax Act. The question thus arises how wide (or narrow) should the interpretation of those activities be? In other words what is the scope or ambit of the given definition? Too wide an interpretation might lead to the exclusion of certain types of taxpayers that were actually intended by government to benefit from section $12 \varepsilon$ and the Sixth Schedule of the Act.

\section{OBJECTIVES AND RESEARCH METHODOLOGY OF THE STUDY}

The problem statement in section 2 makes it clear that the current definitions of the concepts of 'professional service' and 'personal service' are vague and ineffective. The main objective of this article is to identify and highlight the shortcomings of the definitions and to explore alternative criteria for identifying small businesses.

The research was conducted through a review of existing literature such as recognised dictionaries, articles written by local and international academics, South African income tax case law, as well as other local and international legislation. This was done in order to establish 
a clear and unambiguous meaning of terms such as 'professional' and 'profession'. Practical examples were also used to illustrate the problem at hand. Possible solutions were investigated and recommendations made which might eradicate any confusion and interpretation problems in future. To make these recommendations, relevant local and international legislation, views and perspectives were investigated.

To meet the abovementioned objectives, the article was structured in the following manner:

- Investigation of the definition of the terms 'professional' and 'profession' by dictionaries and academic writers;

- A discussion of certain practical examples which highlights the problems posed by the current definitions used in the Act;

- An investigation into the definition of 'professional' and other terms associated therewith by South African income tax case law and other current South African legislation;

- A discussion of the meaning of the word 'professional' and associated terms from an international perspective;

- An investigation of alternative criteria for classifying a small business using appropriate international and South African legislation;

- Conclusions and recommendations.

\section{DEFINITION OF THE TERMS ‘PROFESSIONAL’ AND ‘PROFESSION’}

It is deemed necessary for purposes of this article to investigate the meaning of the terms 'professional' and 'profession' by sources other than the Act. Two of the most authoritative English dictionaries define the word 'professional' as follows:

The Oxford Paperback Dictionary (Fourth Edition) (2000:637):

Professional adjective $\quad l$ of or belonging to a profession or its members.

2 having or showing the skill of a professional.

3 doing a certain kind of work to make a living.

Noun $\quad l$ a person working or performing for payment.

2 someone highly skilled.

Collins English Dictionary (Fifth Edition) (2011):

Professional adjective $\quad l$ of, relating to, suitable for, or engaged in as a profession.

2 engaging in an activity for gain or as a means of livelihood.

3 extremely competent in a job, etc.

4 undertaken or performed for gain or by people who are paid.

Noun 5 a person who belongs to or engages in one of the professions.

6 a person who engages for his livelihood in some activity.

7 a person who engages in an activity with great competence.

The online dictionary BusinessDictionary.com (2011) defines the word professional as:

1. Person formally certified by a professional body of belonging to a specific profession by virtue of having completed a required course of studies and / or practice. And whose competence can usually be measured against an established set of standards.

2. Person who has achieved an acclaimed level of proficiency in a calling or trade. 
The word "profession" is further defined by the dictionary as:

Occupation, practice, or vocation requiring mastery of a complex set of knowledge and skills through formal education and / or practical experience. Every organized profession (accounting, law, medicine, etc.) is governed by its respective professional body.

Strauss, Jansen and Lubbe (2004:92) are of the opinion that Pretorius's definition (1985:14-16) of the word 'profession' is a suitable and appropriate one. Pretorius (1985:14-16) defines a profession as 'an occupation with an elevated status which requires a degree of theoretical and practical training, knowledge and skills and whose members are subject to a code of ethics and that is governed by a professional body' (translation).

After analysing the abovementioned definitions, it is clear that there are different degrees to which a person could be deemed professional i.e. membership of a profession, some acquired skill and even the mere participation in an activity itself. If one should analyse the definition of professional as given by these dictionaries and scholars the following questions arise. Does this mean that a person should have some kind of specific qualification? And if so, should the qualification be obtained from a specific institution? Will this qualification result in the person being 'highly skilled'? Must the person rendering the service be a member of an accredited institution? What then will be deemed a proper qualification and or level of accreditation that will satisfy the criteria set by the Sixth Schedule and section 12\&? Furthermore what requirements must an institution meet in order for it to be deemed 'accredited' or 'professional'? Is there the proverbial 'litmus paper test' which will determine whether a service is professional or not? At present there are no clear and unambiguous answers to these questions. The following section makes use of practical examples illustrating the problem at hand.

\subsection{Practical examples of the dilemma imposed by the definitions}

To illustrate the practical dilemma imposed by the definitions, the following scenarios should be considered for four of the 23 activities listed by the Sixth Schedule and section $12 \varepsilon$ :

\section{Accounting}

A person who has passed grade 12, but has undertaken no further studies at a tertiary institution, completes and submits tax returns for clients in exchange for payment. This person's turnover is less than Rl million during the year of assessment. Is the service being rendered professional? Although a service is definitely being rendered, does this person still need to have an accounting degree, diploma or some other kind of qualification or membership to an accredited institution to make the service professional? Or does the situation change if this person has obtained his or her Chartered Accountant qualification, is a member of the South African Institute of Chartered Accountants ('SAICA') and has a master's degree in taxation?

Health

Traditional healers, such as witch doctors (or 'sangomas'), serve as a perfect example for the vague definition of professional service given by the Sixth Schedule and section $12 \varepsilon$. These traditional healers provide health services to their communities by issuing them with traditional medicine and advice in exchange for payment. Due to the fact that he or she renders health services, does it automatically make him or her professional? Or is something more required, like a degree in medicine or psychology? Can a traditional healer be placed in the same category as a neurosurgeon who has obtained medical degrees from renowned universities worldwide? 
The scope of activities that can be deemed a sport can potentially be very broad. It can include activities such as marketing, administration, coaching and playing itself. This seems to be ambiguous - consider a national sports coach such as the former Springbok rugby coach, Jake White. His services can be deemed to be professional because he was a full-time rugby coach, attended various rugby coaching clinics, coached at international level and achieved considerable success. White's situation thus poses no problem in determining whether his services are professional or not. His pedigree as a coach is a contributing factor to his services being deemed professional and clearly puts him in the 'professional' bracket.

In sharp contrast to the previous scenario, consider a person who in his spare time coaches a primary school's rugby team. He receives payment from parents and / or the school. He played rugby at school but has no formal training as a rugby coach. Is his service to the rugby team a service in sport? If yes (for it seems to be so), then his service is professional according to the Sixth Schedule and section $12 \varepsilon$ on the mere fact that it is a service rendered in the field of sport. The vast difference between the levels of professionalism in these two examples, both falling within the definition of 'professional service', raises the question whether such a result could have been the legislature's intention. Clearly in White's case the question of professionalism has been answered but can the same be said for the primary school rugby coach?

\section{Consulting}

It is foreseen that this activity will probably result in the most arguments due to its meaning. The Oxford Paperback Dictionary (Fourth Edition) (2000:171) defines 'consulting' as follows:

'consulting (adjective) - giving professional advice'

Furthermore, the word 'consultant' is defined as follows by The Oxford Paperback Dictionary (Fourth Edition), (2000:171):

'consultant (noun) - a person qualified to give expert professional advice.'

The use of the words 'professional' and 'expert' infers some kind of qualification needed by the person rendering the service. This, however, is not indicated by the Sixth Schedule or by section 12E. According to Clegg and Stretch (2010a) trades such as electricians and plumbers are excluded from professional services. But, if one considers the trade of a plumber and he is, for example, summoned to inspect building plans and has to give advice on the location of water pipes, suitability of certain types of water pipes for the project as well as bathroom and kitchen fittings required, would that not be considered consulting for the purposes of the Sixth Schedule and Section 12E? Or should the plumber be a member of some kind of plumbing association or have mastered some kind of plumbing course? Does the mere fact that the plumber gives advice to his client make his service professional? It is, therefore, interesting to note that Clegg and Stretch (2010b) exclude plumbers and electricians from professional service.

It is submitted that the preceding four scenarios offer a lot of food for thought. All of the 23 listed activities in the Sixth Schedule and section $12 \varepsilon$ can be dissected as was done with the abovementioned four activities, to highlight the problematic nature of the words 'professional service' as used by the Sixth Schedule and section $12 \varepsilon$. This, however, is not required, as the issues of concern have been clearly and unequivocally identified. The fact remains that certain types of taxpayers, who operate small businesses and who are supposed to benefit from small business tax incentives, are prohibited from making use thereof due to deficiencies in the parameters set by section $12 \varepsilon$ and paragraphs $l$ and $3(b)$ of the Sixth Schedule. In the section 
which follows the South African Income Tax Case Law definitions of the word 'professional' and terms associated therewith are investigated.

\title{
4.2 South African Income Tax Case Law definitions of 'professional' and terms associated therewith
}

In the income tax court case ITC 166461 SATC 383 ('ITC 1664') the court commented on the meaning of the concept 'professional services'. President Smith J, on page 388 of the case, stated that when one has to determine whether or not a service has been provided by someone 'in his professional capacity', one has to look at the person who provided the services and ascertain whether he or she has the necessary qualifications or skills to be able to say that he or she was acting in a professional capacity.

In Kadalie v Hemsworth NO 1927 TPD 862 ('Kadalie') at 866 Grindley-Ferris, J said:

I find that 'profession' has been defined as 'a calling superior to that of a mere trade or handicraft,' and also any calling or occupation involving special mental and other attainments or discipline, as editing, acting, engineering, authorship, etc.

According to president Smith J, judicial decisions about the nature of professions occur principally in tax cases where the issue is whether or not the taxpayer is carrying on a profession. In Commissioner of Inland Revenue v Maxse [1919] IKB 647 ('Maxse'), Scrutton, LJ approached the matter in the following way:

\begin{abstract}
But it seems to me as at present advised that a 'profession' in the present use of language involves the idea of an occupation requiring either purely intellectual skills, or of manual skill controlled, as in painting and sculpture, or surgery, by the intellectual skill of the operator, as distinguished from an occupation which is substantially the production or sale or arrangements for the production or sale of commodities. The line of demarcation may vary from time to time. The word 'profession' used to be confined to the three learned professions, the Church, Medicine and Law. It has now, I think, a wider meaning.
\end{abstract}

The matter arose again in Carr v Inland Revenue Commissioners [1944] 2 Al/ ER 163. In that case Du Parcq, LJ said at page 166:

\begin{abstract}
I think that everybody would agree that, before one can say that a man is carrying on a profession, one must see that he has some special skill or ability or some special qualifications derived from training or experience. Even then one has to be very careful, because there are many people whose work demands great skill and ability and long experience and many qualifications who would not be said by anybody to be carrying on a profession.
\end{abstract}

Analysing the abovementioned rulings it can be inferred that for a person to render a professional service, the person has to possess a special skill or qualification that distinguishes him from the layman. The courts also indicated that it is not always an easy process to distinguish whether someone is professional or not, and it would often depend on the type of service performed and the skills or qualifications required to perform that service. Smith, J also commented on the role of the courts in the interpretation of statutory provisions and refers to the cardinal rule of interpretation set out by Kelleway (1995:92-94):

The cardinal rule is that a provision in a statute should be so construed that, if it can be prevented, no clause, sentence or word in the provision shall be regarded as superfluous, void or insignificant, that is, effect must be given, where possible, to every word, unless necessity or absolute intractability of language indicates otherwise... The conclusion to be drawn, which clarifies the principle to be applied in a proper case, is as follows: Every word 


\begin{abstract}
in a provision of a statute must be given its accepted meaning and cannot be treated as surplusage if in the context in which it is used, meaning can be given to it, it being presumed, moreover, that the legislature is not repeating what it said before. $0 n$ the other hand, if its presence raises doubt as to the meaning of the provision but its elimination determines the clear meaning of the provision, it must be treated as surplusage and in such a case of elimination it cannot be used to qualify or amend the rest of the provision.
\end{abstract}

Interpreting Kelleway's conclusion it is clear that the phrase 'professional service' has to be given its accepted meaning and must be interpreted within the correct context. By giving the phrase the meaning of 'any / a service in the field of ...' and linking it to a list of activities not clearly defined, the provision certainly deviates from this interpretation principle. It is clear from the analysis of the abovementioned case law that the word 'professional' and subsequently the phrase 'professional service' currently do not carry the accepted meaning, i.e. that of a service or quality which requires a certain skill set, standard of knowledge, expertise and appropriate qualification. In the following section other South African legislation was investigated to establish whether a more effective and clear definition of the word 'professional' exists.

\title{
4.4 The use of the word 'professional' in other current South African legislation
}

Other South African legislation was reviewed to identify definitions of the word 'professional' or terms associated with the word 'professional'. This was done to draw a comparison between the definition used for income tax legislation purposes and other legislation and to establish its effectiveness.

The Financial Advisory and Intermediary Services Act, 2002 (Act No 37 of 2002) ('FAISA') contains definitions for terms such as 'professional knowledge' and 'professional skills' and also sets out criteria and definitions of qualifications. 'Professional knowledge' is defined by the FAISA as: 'topics that make up subjects related to the financial services industry as well as other related business disciplines that, together, constitute the essential body of knowledge of professionals in the financial services industry'. 'Professional skills' means: 'the various abilities to apply professional knowledge and professional values, ethics, and attitudes appropriately and effectively in a professional context, including technical and functional skills, organisational and business management skills, personal, interpersonal and communication skills, as well as intellectual skills'.

The National Qualifications Framework Act, 2008 (Act No. 67 of 2008) ('NQFA') defines the term 'professional body' as 'any body of expert practitioners in an occupational field, and includes an occupational body' and the term 'professional designation' as 'a title or status conferred by a professional body in recognition of a person's expertise and right to practise in an occupational field'. From the definitions provided by the FAISA and the NQFA, it is clear that these acts link the term 'professional' to a level of expertise and a certain set of skills. These levels and skills have to be obtained by a person, before his or her service can be deemed to be professional. It is submitted that these definitions (interpreted within the correct context) are much more effective and clearer than those currently used in income tax legislation and confirms the need for a review of the current section $12 \varepsilon$ and Sixth Schedule definitions.

With regard to specific services, legislation such as the Medical Schemes Act No. 131 of 1998 and the National Health Act No. 61 of 2003 defines services relevant to the medical profession. These definitions can be viewed as comprehensive and clear and they remove any uncertainty from the 
meaning of these services. In section $12 \varepsilon$ and paragraph 1 of the Sixth Schedule of the Act a number of services are listed, but not defined. A need for the definition of these services is thus required.

\subsection{The meaning of the word 'professional' and concepts associated therewith from an international perspective}

The American physicians Epstein and Hundert (2002:226) investigated the definition and assessment of professional competence in the medical profession. They defined professional competence as 'the habitual and judicious use of communication, knowledge, technical skills, clinical reasoning, emotions, values, and reflection in daily practice for the benefit of the individual and community being served'. Competence builds on a foundation of basic clinical skills, scientific knowledge, and moral development. It includes a cognitive function, acquiring and using knowledge to solve real-life problems. Competence also depends on habits of mind, including attentiveness, critical curiosity, self-awareness, and presence. Professional competence is developmental, impermanent and context-dependent (Epstein \& Hundert, 2002:227).

Epstein and Hundert (2002:227) also supports Schon's argument that professional competence is more than factual knowledge and the ability to solve problems with clear-cut solutions: it is defined by the ability to manage ambiguous problems, tolerate uncertainty and make decisions with limited information. The Australian Health Insurance Act 1973 No. 42 of 1974 also provides a comprehensive and detailed definition of professional services (within the context of the medical profession) in section 3 of the Act.

A study was undertaken in the late 1970s by the Swedish academic, Evert Gummesson, to define professional services within a Swedish context. Gummesson (1978:90) argued that, firstly, a professional service must be distinguished from other products offered on the market. In identifying professional services in Sweden, the following criteria were found to fulfil that purpose:

- The service should be provided by qualified personnel, be advisory and focus on problem solving;

- The professional should have an identity, i.e., be known in the market for his specialities and under a specific name such as 'architect' or 'management consultant'.

Gummesson (1978:90) also argued that definitions of the services themselves (for example accounting, auditing or engineering) are helpful as they specify in a concrete way what characterises a certain professional service. A number of fundamental components of the professional service gradually developed. Eventually, it was found that eight components covered the services and that they were of general application, i.e., valid irrespective of the type of professional service. These components were (Gummesson, 1978:91-93):

1. Specialist know-how, experience and methods - the professional firm offers expert knowledge and methods of carrying out certain types of assignments;

2. Individual professionals - they are the carriers of the specialist know-how and their personalities, motivation, social skills, creativity and stamina play an important part;

3. Other resources and attributes - apart from expert know-how and individual professionals, the professional service firm will have other essential resources and qualities such as the size of the professional firm, the number of local offices and the use of computers; 
4. Diagnosis, problem and goal formulation - a correct definition of the problem and practical goal for the assignment are essential;

5. The way of operating the assignment - the assignment may be concentrated in time or spread over a period, furthermore the professional may operate closely with the client's personnel or he may work very much on his own;

6. The solution to the problem - the work of the professional must lead to some kind of solution to the client's problem;

7. Implementation of the solution - the professional is more often than not seen as an investigator and an adviser who should not take part in implementation. However, this varies between professions and between firms within the professions;

8. The result of the implemented solution - the assignment is not terminated until the result has been achieved.

According to Gummesson (1978:91) components (1), (2), (5) and (6) are necessary components in any professional service. The others may or may not be present. The components reflect the breadth of the service. Quality, seen as the value of the service from the client's point of view, is also dependent on the depth of the service, i.e., the skill with which the service is rendered and the attention that is devoted to it. It is argued that the quality of a professional service is a subjective measure (Gummesson, 1978:93).

During 2009 a study was undertaken into a practical definition of professional behaviour in the medical profession in Australia. Rogers and Ballantyne (2010:250) stated that the wide variety of definitions of medical professional behaviour in the literature reflected the challenges in defining this element of medical practice. They proposed the following five domains of professional behaviour with regards to medical practice:

1. Responsibility (for example, conscientiousness and record keeping);

2. Relationships with and respect for patients;

3. Probity and honesty;

4. Self-awareness and capacity for reflection; and

5. Collaboration and working with colleagues.

This approach is deemed to be practically useful because it focuses on behaviours that can be observed and recorded (Rogers \& Ballantyne, 2010:254).

The discussion above on the detailed definition and analysis of the word 'professional' and concepts associated therewith from an international perspective, specifically in the medical profession, highlights the need for clearer and more precise definitions of the word 'professional' in other fields of service delivery. The question can be asked why, if the medical profession is capable of compiling efficient definitions and setting clear and unambiguous parameters for professional services, behaviour and competence, the same could not be done for other professions and service delivery industries. The definition of professional services (or personal services as in section 12E's case), therefore, cannot be constructed in a synoptic and vague manner, as it is clear that defining the word 'professional' for different activities is challenging and complex. In the section that follows alternative criteria for classifying a business as a small business are investigated. 


\section{ALTERNATIVE CRITERIA FOR CLASSIFYING A BUSINESS AS A SMALL BUSINESS}

It is submitted that an investigation into the classification criteria of a small business from an international perspective might identify useful principles or aids in simplifying the definition of a small business. These principles or aids could be used within a South African context to allow more taxpayers, who genuinely qualify as small businesses, to make use of the income tax incentives available to small businesses.

According to Filion (1990:33) the United States of America (USA) was the first country to define a small business. The first official legal definition of a small business in the United States was given by the section 18A of the Selective Service Act of 1948 which gave the following definition: "a business enterprise shall be determined to be "small business" if its position in the trade or industry if which it is part is not dominant, the number of employees does not exceed 500 and it is independently owned and operated ...' (Filion, 1990:34). The main elements of this definition were later used by the Small Business Act of 1953 which used the following definition: '.... s small business concern shall be deemed to be one which is independently owned and operated and which is not dominant in its field of operation. In addition to the foregoing criteria the Administrator, in making a detailed definition, may use these criteria, among others: number of employees and dollar volume of business ...' (Filion, 1990:34). The elements constituting the foregoing definition was summarised by Filion (1990:34) as follows:

1. The enterprise must be independently owned and operated;

2. It must not be dominant in its field of operation; and

3. Two quantitative criteria may be applied: number of employees and volume of business.

According to Filion (1990:35) it was understood that the 'volume of business' meant the total sales or revenue of the business. Filion (1990:35) indicated that enormous variations could be seen from one sector to another and that quantitative criteria should be set taking into account the development and gradual automation of each business sector. He also points out that, on the whole, the criteria of number of employees and sales seem to be those used most often by countries such as the USA and Canada (Filion, 1990:37). The USA also uses assets, net worth, common stock issue, equity capital, profit or net income (Filion, 1990:42).

In Britain, other criteria used include turnover, net asset value, number of vehicles and profit (Filion, 1990:42). In Japan, the number of employees and the criteria related to capital are the main criteria used. The Japanese have also used different limits to differentiate a small business, depending on the sectors of the economy. In France, the criterion of the number of employees is used together with that of equity capital. In Korea, quantitative criteria of assets and number of employees are used. In Quebec, the asset criterion is sometimes used, but the main criterion is that of number of employees and manufactured added value (Filion, 1990:43).

According to Filion (1990:37-38) the three qualitative criteria mentioned in most definitions, including those from the USA and Canada, are:

1. Independently owned and managed - this independence reflects the close relationship existing between capital and management, as the person responsible for the management of the small business is also the owner. He makes decisions that have implications for his own money. This criterion is a basic one and is undoubtedly the 
most definite and most important characteristic that makes a small business what it is;

2. Managed in a personalised way - it is implied that those who own the enterprise also manage it in their own way. It implies they are present most of the time and make a living out of it. When the enterprise reaches a certain level of growth, it becomes possible in many cases for the owner not to work there on a daily basis. However, he or she continues to make important decisions. After a while (it can be many years in some cases) the enterprise will integrate specialists and will become managed in a more professional way. It is a sign that it is no longer a small, fragile business. This criterion complements the first one; and

3. Small market share - this implies that the enterprise must not be dominant in its market. This is ambiguous and is also difficult to apply, since it requires a precise definition of what a market is, what its boundaries are and what constitutes a small share of it.

Filion (1990:45) states that assets, total sales, turnover or added value are objective criteria and the most interesting after number of employees. They are absolute figures which can, however, be distorted. Nevertheless, they can present some advantages for the purpose of statistical compilation, especially in countries where the inflation rate is low. Filion (1990:45) also states that further discussion is possible on the subject of quantitative criteria. There is no absolute solution. It is important to adjust to what is done by trading partners and service industries and to choose logical criteria, which, proportionally, are at the same level as theirs. Choice of criteria should depend on specific circumstances.

Carland, Hoy, Boulton and Carland (1984:358) proposed the following definitions for a small business venture and small business owner, respectively:

- Small business venture - A small business venture is any business that is independently owned and operated, not dominant in its field, and does not engage in any new marketing or innovative practices;

- Small business owner - A small business owner is an individual who establishes and manages a business for the principal purpose of furthering personal goals. The business must be the primary source of income and will consume the majority of one's time and resources. The owner perceives the business as an extension of his or her personality, intricately bound with family needs and desires.

Scott and Bruce (1987:45) state that it is necessary to define a small business to avoid the misunderstanding of the term. They adapted the American Committee for Economic Development's definition, which states that a small business is a business whose:

- Management is independent - usually the managers are also the owners;

- Capital is supplied and ownership is held by an individual or small group; and

- Area of operations is mainly local - workers and owners are in one home community, but markets need not be local.

In South Africa, according to section 1 of the National Small Business Act No. 102 of 1996 (NSB Act) a small enterprise means:

a separate and distinct business entity, together with its branches or subsidiaries, if any, including cooperative enterprises, managed by one owner or more predominantly carried on in any sector or sub-sector of the economy mentioned in column $l$ of the Schedule and 
classified as a micro-, a very small, a small or a medium enterprise by satisfying the criteria

mentioned in columns 3,4 and 5 of the Schedule

The sectors covered in column 1 are agriculture, mining and quarrying, manufacturing, electricity, gas and water, construction, retail and motor trade and repair services, wholesale trade, commercial agents and allied services, catering, accommodation and other trade, transport, storage and communications, finance and business services, community, social and personal services. It should be noted, however, that none of these sectors is defined in the NSB Act. In summary, the criteria set by columns three, four and five are the total full-time equivalent of paid employees, total turnover and total gross asset value (fixed property excluded) respectively. These criteria are similar to those used by other countries previously discussed. It follows that South Africa does apply internationally used and recognised criteria for identifying a small business.

Consideration of the above concepts could, therefore, prove helpful when one has to identify a small business. A key principle, which regularly came to the fore, is that a combination of qualitative and quantitative measures should be used in the small business classification process. It is, furthermore, important that these measures should be industry- and servicesector specific and applied within the correct context. Small business income tax legislation in Australia is discussed in the following section.

\section{SMALL BUSINESS INCOME TAX LEGISLATION IN AUSTRALIA}

South African income tax legislation has numerous similarities with Australian income tax legislation due to the fact that it originated from the Australian New South Wales Act of 1895 (Huxham \& Haupt, 2010:6). Judge Wunsh also highlighted the comparability of the South African income tax structure to that of Australia in CIR v Manganese Metal Co (Pty) Ltd [1996] 58 SATC1. Australia is a 'first world country' and member of the Organisation for Economic Cooperation and Development (OECD) who are trendsetters with regard to the establishment of uniform economic standards and application of prudent, sensible economic practice in the fields of economics, taxation and accounting (0ECD Member Countries, [s.a.]). An investigation into the definition of a small business for Australian income tax purposes is, therefore, deemed insightful and could possibly lead to identifying useful principles that can be successfully applied within a South African income tax context. For the purpose of this research article, the relevant Australian income tax legislation to be investigated is the Income Tax Assessment Act 1997 (ITAA97). Section 328-110 of the ITAA97 defines a small business. The definition reads verbatim as follows:

328-110 Meaning of small business entity

(1) You are a small business entity for an income year (the current year) if:

(a) you carry on a business in the current year; and

(b) one, or both of the following applies:

(i) you carried on a business in the income year (the previous year) before the current year and your aggregated turnover for the previous year was less than $\$ 2$ million;

(ii) your aggregated turnover for the current year is likely to be less than $\$ 2$ million. 
(3) However, you are not a small business entity for an income year (the current year) because of subparagraph l(b)(ii) if:

(a) you carried on a business in each of the 2 income years before the current year; and

(b) your aggregated turnover for each of those income years was $\$ 2$ million or more.

(4) You are also a small business entity for an income year (the current year) if:

(a) you carry on a business in the current year; and

(b) your aggregated turnover for the current year, worked out as at the end of that year, is less than $\$ 2$ million.

According to section 995-1 of ITAA97 a business includes any profession, trade, employment, vocation or calling, but does not include occupation as an employee. Section 328-115 of ITAA97 defines aggregated turnover. Aggregated turnover includes all income (according to ordinary concepts) derived by a taxpayer. Section 328-120 lists amounts excluded from aggregated turnover. Inspection of this list revealed no exclusion of income derived from services (professional or not). Therefore, no emphasis is placed on the type of trade that the taxpayer carries on (as is the case in section $124 \varepsilon$ and the Sixth Schedule). An employee is clearly excluded from being classified as a business entity. The list of exclusions is, furthermore, considered to be condensed, straightforward, clear and unambiguous.

The structure used to define a small business in Australia is similar to the structure used in section 23(1) of the South African Value-Added Tax Act No. 89 of 1991 (the VAT Act) to determine whether a person has to register for Value-Added Tax (VAT) or not. It is submitted that section 23(1) of the VAT Act has been applied with considerable success by the South African Revenue Services (SARS) to regulate the registration process and that this section is easily comprehensible by any person who needs to ascertain whether they should be a registered VAT-vendor or not.

An analysis of section 328-110 indicated that the Australian definition of a small business entity makes use of two key elements to identify a small business entity. The first element is qualitative, namely whether the taxpayer is carrying on a business (as defined), and the second element is a quantitative measure, namely the aggregate turnover derived by the entity for specific periods (currently a benchmark of $\$ 2$ million is used). The structure used by the Australian income tax authority (The Australian Taxation Office (ATO)) is, therefore, a simplified one and deemed to be extremely user-friendly.

In South Africa section 37G of the Act, introduced in 1995, allows the Minister of Finance to make regulations to facilitate compliance with the Act by certain natural persons. The objective of the section is to simplify tax compliance by small business undertakings. To this end the Minister is empowered to make regulations dealing with natural persons who conducts a business through such small business undertakings, whether alone or in partnership with other natural persons. A regulation made by the Minister in terms of this provision may prescribe what constitutes a small business undertaking, having regard to a variety of circumstances such as the nature of the undertaking; the turnover, taxable income or profit of the undertaking; the number of persons employed in the undertaking; the nature and extent of other income derived by the proprietor or partners; and any other feature which, in the opinion of the Minister, indicates that an undertaking should be regarded as a small business undertaking (s $37 \mathrm{G}(2)(a)$ ) (De Koker, 2011a). 
However, to date no such regulations have been made, and according to Clegg and Stretch (2010b) the provisions of the section are, at this stage, of academic interest only. De Koker (2011b) also noted that it is evident from the reference to 'natural persons' that the provisions of this section do not extend to companies, close corporations and trusts. In terms of paragraph 57 of the Eighth Schedule of the Act there is a special concession when a capital gain is made on the disposal of 'small business assets'. The concession, which is available only to a natural person, requires that a person disregard a capital gain made in certain instances (Stein, 2011).

A 'small business' is defined in paragraph 57 as 'a business where the market value of all its assets does not exceed R10 million as at the date of disposal of its assets or interests'. This definition only applies to the Eighth Schedule of the Act and is only relevant for capital gains tax purposes. It is respectfully submitted that this definition can be construed as being too simplistic and does not capture the true essence of what a small business is (as discussed earlier in this article). The definition can, however, in combination with other suggested criteria, be used efficiently and successfully to identify a small business.

\section{CONCLUSION AND RECOMMENDATIONS}

A 'professional (personal) service', it seems, is currently defined as though any service rendered in any one of the activities listed in paragraph 1 of the Sixth Schedule and section $12 \varepsilon(4)(d)$ can be deemed professional, ignoring levels of qualification, accreditation and even definitions of the activities themselves. If one follows the definition of professional and personal service in the Sixth Schedule and section $12 \varepsilon$, the mere fact that a service has been rendered in the field of one or more of the listed activities, makes that service professional. The scope of the definition seems, without a doubt, to be too wide and too vague. Clear and unambiguous parameters regarding the definition of 'professional service' need to be set by the legislature to dispose of any uncertainties regarding its scope and meaning. It is recommended that each activity listed in paragraph 1 of the Sixth Schedule and section $12 \varepsilon(4)(d)$ needs to be defined with care and thoroughness.

The Portfolio Committee on Finance has by its own admission conceded in their Response Document to the Revenue Laws Amendment Bill, 2008 that the scope of the definition of 'personal service' in section $12 \varepsilon$ and 'professional service' in the Sixth Schedule of the Income Tax Act will be reviewed in future. This clearly indicates that the 'professional services' issue is problematic. To date, no such review has taken place. It seems, therefore, that, if a taxpayer is rendering a service, the taxpayer must ask himself whether his service is considered professional enough to exclude him from the concessions available to small businesses under the Sixth Schedule and section $12 \varepsilon$.

De Koker (2011b) questions the significance of the term 'personal services' as used in section 12E. He states that from the definition of a $S B C$, it may be seen that a company or close corporation will not qualify as a SBC if more than $20 \%$ of its total receipts and accruals (but not those of a capital nature) and capital gains consists collectively of investment income and income from the rendering of personal services. It is critical, therefore, to identify the personal services provided by the company or close corporation and to determine in each year of assessment whether the income from this source together with the investment income exceeds $20 \%$ of its non-capital receipts and accruals and capital gains. 
Alternatively, it is submitted that the definition of a small business (or micro business) must be amended and simplified to erase any uncertainty about whether a taxpayer qualifies as one or not. For this purpose the legislature can consider regulations similar to those used by Australian income tax legislation in section 328-110 of the ITAA97. This could be done by making use of section $37 \mathrm{G}$ of the Act with appropriately structured regulations. Turnover, revenue and number of employees could be used as primary criteria for different industry and service sectors. It should be noted, however, that the quantitative measures should be industry specific, carefully set and applied within the correct context. It is also recommended that the qualitative measure whether the business is independently owned and managed, should be used as a secondary criterion to identify a small business. For the purpose of this requirement, capital must be supplied and ownership must be held by an individual or at least a small group of individuals.

Straightforward parameters should, therefore, be used, leaving no room for uncertainty. This might allow previously excluded small businesses to make use of the income tax incentives intended for small business. This could possibly lead to more small businesses becoming part of the income tax system, economic growth, and job creation and could ultimately result in an increase in income tax revenue for the South African government.

\section{LIST OF REFERENCES}

BusinessDictionary.com. (2011). [Online]. Available: http://www.businessdictionary.com/definition /professional.html. (Accessed 19 November 2011).

Carr v Inland Revenue Commissioners (1944) 2 All ER 163.

Carland, J.W., Hoy, F., Boulton, W.R. \& Carland, J.C. (1984). Differentiating Entrepreneurs from Small Business Owners: A Conceptualization. The Academy of Management Review, 9(2), pp. 354-359.

Clegg, D. \& Stretch, R. (2010a). Small business undertakings. Income Tax in South Africa [Online]. Available: http://www.lib.sun.ac.za.ez.sun.ac.za/nxt/gateway.dll?f=templates $\$ f n=$ default.htm\$vid= mylnb:10.1048/enu. (Accessed 28 0ctober 2011).

Clegg, D. \& Stretch, R. (2010b). Taxation of micro businesses. Income Tax in South Africa [Online]. Available: http://www.lib.sun.ac.za.ez.sun.ac.za/nxt/gateway.dll/7b/6d/0kfa/aqmk. (Accessed 14 November 2011).

Collins English Dictionary, Fifth Edition. (2000). [Online]. Available: http://www.credoreference. Com.ez.sun.ac.za/search.do?query=professional\&subject=all\&scope $=$ title\&title=227\&view=facet. (Accessed 25 October 2011).

Commissioner of Inland Revenue v Manganese Metal Co (Pty) Ltd (1996) 58 SATC1.

Commissioner of Inland Revenue v Maxse (1919) IKB 647.

De Koker, A.P. (201la). Small Business Corporations. Silke on South African Income Tax [0nline]. Available: http://www.lib.sun.ac.za.ez.sun.ac.za/nxt/gateway.dll/7b/ae/0aa/bijtb. (Accessed 5 November 2011).

De Koker, A.P. (2011b). Small business undertakings. Silke on South African Income Tax [Online]. Available: http://www.lib.sun.ac.za.ez.sun.ac.za/nxt/gateway.dll?f=templates\$fn=default.htm\$vid= mylnb:10.1048/enu. (Accessed 25 0ctober 2011). 
Epstein, R.M. \& Hundert, E.M. (2002). Defining and Assessing Professional Competence. Journal of the American Medical Association, 287(2), pp. 226-235.

Filion, L.J. (1990). The need for a definition of small business. Journal of Small Business and Entrepreneurship, 7(2), pp. 33-46.

Gummesson, દ. (1978_. Toward a Theory of Professional Service Marketing. Industrial Marketing Management, 7: 89-95.

Huxham, K. \& Haupt, P. (2010). Aantekeninge oor Suid-Afrikaanse Inkomstebelasting. Roggebaai: Hedron Tax Consulting and Publishing CC.

Income Tax Assessment Act 1997 Act No. 38 of 1997 of Australia as amended.

ITC 1664 date?61 SATC 383.

Kadalie v Hemsworth date? NO 1927 TPD 862.

Kelleway, દ.A. (1995). Principles of legal interpretation of statutes, contracts and wills. Durban: Butterworths.

Legal and Policy Division of the South African Revenue Service. (2011). Tax Guide for Micro Businesses 2011/2012 [Online]. Available: http://www.sars.gov.za/home.asp?pid=4150. (Accessed 23 July 2012)

Mkhize, V. (2011). A Critical Analysis of the Tax Implications for Small and Micro Businesses. Port Elizabeth: Nelson Mandela Metropolitan University.

National Treasury. (2008). Explanatory Memorandum on the Revenue Laws Amendment Bill, 2008 (Accessed 31 August 2011).

OECD Member Countries. [S.a.] [Online]. Available: http://www.oecd.org/countrieslist /0,335] ,en_33873108_338444430_1_1_1_1_1,00.html. (Accessed 11 November 2010).

Pretorius, J.T. (1985). Aanspreeklikheid van maatskappy-ouditeure teenoor derdes op grond van wan-voorstelling in die finansiële state. Publikasiekomitee van die Randse Afrikaanse Universiteit.

Republic of South Africa. (1962). Income Tax Act No. 58 of 1962. Pretoria: Government Printing Works. Republic of South Africa. (1991). Value-Added Tax Act No. 89 of 1991. Pretoria: Government Printing Works.

Republic of South Africa. (1996). National Small Business Act No. 102 of 1996. Pretoria: Government Printing Works.

Republic of South Africa. (1998). Medical Schemes Act No. 131 of 1998. Pretoria: Government Printing Works.

Republic of South Africa. (2002). Financial Advisory and Intermediary Services Act No. 37 of 2002. Pretoria: Government Printing Works.

Republic of South Africa. (2003). National Health Act No. 61 of 2003. Pretoria: Government Printing Works.

Republic of South Africa. (2008). National Qualifications Framework Act No. 67 of 2008. Pretoria: Government Printing Works.

Republic of South Africa. (2008). Revenue Laws Amendment Act No. 60 of 2008. Pretoria: Government Printing Works. 
Rogers, W. \& Ballantyne, A. (2010). Towards a practical definition of professional behaviour. Journal of Medical Ethics, 36(4), pp. 250-254.

Scott, M. \& Bruce, R. (1987). Five Stages of Growth in Small Business. Long Range Planning, 20(3), pp. $45-52$.

Stein, M. (2011). Disposal of small business assets. Capital Gains Tax - Stein [Online]. Available: http://www.lib.sun.ac.za.ez.sun.ac.za/nxt/gateway.dll?f=templates $\$ f n=$ default.htm $\$ v i d=m y l n b: 10$. 1048/enu. (Accessed 11 November 2011).

Stiglingh, M., Koekemoer, A., van Schalkwyk, L., Wilcocks, J.S., de Swardt, R. \& Jordaan, K. (2011). Silke: South African Income Tax 2011. Pietermaritzburg: LexisNexis.

Strauss, P.M.S., Jansen, R-M \& Lubbe, D.S. (2004). Professionele anspreeklikheid van ouditeure teenoor derdes op grond van nalatigheid. Tydskrif vir Regswetenskap, 29(2), pp. 91-108.

The Australian Health Insurance Act 1973 Act No. 42 of 1974 of Australia as amended.

The Oxford Paperback Dictionary, $4^{\text {th }}$ edition. (2000). Oxford: Oxford University Press.

The Portfolio Committee on Finance. (2008). Response Document to the Revenue Laws Amendment Bill, 2008 [Online]. Available: http://www.treasury.gov.za/legislation/bills/2008/Revenue\%20Laws \%20Amendment $\% 20$ Bills, $\% 202008 \% 20$ - $\% 20$ Response $\% 20$ Document $\% 20 \% 2021 \% 200$ ctober\% 202008.pdf. (Accessed 2 November 2011). 